\title{
Chromatin Immunoprecipitation (ChIP) Protocol from Tissue
}

Nabila Aboulaich

\section{Materials and Reagents}

1. Frozen tissue

2. Protease inhibitors complete mini pill (F. Hoffmann-La Roche)

3. $1 \mathrm{~kb}$ DNA ladder (Life Technologies, Invitrogen ${ }^{\mathrm{TM}}$ )

4. Protein A- or protein G- agarose (Santa Cruz Biotechnology)

5. Phenol-chloroform-isoamylalchohol (Life Technologies, Invitrogen ${ }^{\mathrm{TM}}$ )

6. Pellet paint (Novagen)

7. General chemicals (Sigma-Aldrich)

8. PBS

9. Hepes

10. Tris- $\mathrm{HCl}(\mathrm{pH} 8.0)$

11. EDTA

12. SDS

13. EGTA

14. $\mathrm{NaCl}$

15. Triton $X-100$

16. Sodium deoxycholate

17. Agarose gel

18. HEPES-NaOH buffer (see Recipes)

19. ChIP lysis buffer (see Recipes)

20. RIPA buffer (see Recipes)

21. Digesting buffer (see Recipes)

\section{Equipment}
1. Centrifuges
2. Sonicator
3. Razor blade
4. Shaker
5. PCR machine 


\section{Procedure}

1. Start with $70 \mathrm{mg}$ of fresh or frozen tissue. Mince the tissue using a clean razor blade in $4.5 \mathrm{ml}$ of ice cold PBS on ice into small pieces.

2. Add freshly made HEPES-formaldehyde solution to a final concentration of $1 \%$ formaldehyde $(0.5 \mathrm{ml}$ of $11 \%$ formaldehyde in HEPES-NaOH.

Note: Make up this solution right before use, enough for one use only).

3. Incubate with mixing at room temperature (RT) for $10 \mathrm{~min}$.

4. Centrifuge the cross-linked tissue at $2,000 \mathrm{rpm}$ for $5 \mathrm{~min}, 4^{\circ} \mathrm{C}$.

5. Wash the tissue in PBS and centrifuge again (twice).

6. Add ChIP lysis buffer $(1.6 \mathrm{ml}$ for $70 \mathrm{mg}$ of starting tissue) with protease inhibitors. Split the sample into two eppendorf tubes, $800 \mu \mathrm{l}$ each and make sure there is roughly the same amount of tissue in each.

7. Sonicate the tissue (keep on ice at all times) to obtain chromatin with an average shear size of $500-1,200 \mathrm{bp}$ (with our lab sonicator this is achieved by sonicating at setting 2, 10 sec per cycle, 6 cycles total).

8. Centrifuge the sonicated chromatin at high speed and pellet the debris from sonication. Pool the two tubes of chromatin for each sample.

9. Run out $5 \mu \mathrm{l}$ of chromatin on a $1 \%$ agarose gel with a $1 \mathrm{~kb}$ DNA ladder to determine shear size. If the size is close to $3 \mathrm{~kb}$, proceed with ChIPs (chromatin with un-reversed crosslinks usually runs slower on a gel and appears larger than the actual size).

10. Save a small aliquot as input control for PCR (5-20\%).

11. Pre-clear chromatin: For this step, use the resin that you intend to use to capture immune complexes after the immunoprecipitation, such as Protein $A$ agarose. Dilute the chromatin in 0.5x RIPA buffer with protease inhibitors and add to $40 \mu \mathrm{l}$ packed, prewashed Protein A agarose. Out of 1,600 $\mu$ l of sonicated chromatin, I use about 100-200 $\mu l$ per IP (depending on how much you see on the gel). Total volume of preclearing mix is $1 \mathrm{ml}$. Incubate for $1 \mathrm{~h}$ or more with rocking at $4{ }^{\circ} \mathrm{C}$ (Note: The purpose of pre-clearing is to remove material in the chromatin that binds non-specifically to the resin). Use one pre-clearing tube for each IP rather than pre-clearing concentrated chromatin in one tube. Spin down the pre-cleared chromatin $(2,000 \mathrm{rpm}, 1 \mathrm{~min})$ and carefully transfer the supernatant to a fresh tube. Add the appropriate antibody to the IP ( $3 \mu \mathrm{g}$, but it depends on antibody) and incubate for $3 \mathrm{~h}$ (or overnight) at $4{ }^{\circ} \mathrm{C}$, with rocking.

12. After immunoprecipitating the protein-DNA complexes, add the IP mixture to fresh prewashed agarose beads/resin and incubate for $1.5 \mathrm{~h}$ at $4{ }^{\circ} \mathrm{C}$. 
13. Spin the IPs at 2,000 rpm for 1 min and remove the supernatant. Wash IPs 3 times with $800 \mu \mathrm{l}$ of $0.5 x$ RIPA buffer (add the buffer, shake the tubes well and then spin down the resin each time, remove supernatant and repeat wash).

14. Add $300 \mu \mathrm{l}$ of digesting buffer and incubate the tubes at $65^{\circ} \mathrm{C}$ for a minimum of $4 \mathrm{~h}$, max overnight to reverse the crosslinks.

15. Add an equal volume of phenol-chloroform-isoamylalchohol to the tubes, vortex and centrifuge at high speed for $10 \mathrm{~min}, 4{ }^{\circ} \mathrm{C}$. Transfer the aqueous supernatant to a fresh tube and ethanol precipitate the DNA. Since the amount of DNA recovered is very little, it is recommended that you use a carrier for precipitation, such as glycogen or pellet paint.

16. Centrifuge ethanol-precipitated samples at top speed for $30 \mathrm{~min}$ at $4{ }^{\circ} \mathrm{C}$ and remove the supernatant. Dry the DNA pellet and resuspend in $20 \mu \mathrm{l}$ of water. Use this DNA for PCR amplification, $2 \mu \mathrm{l}$ per reaction.

\section{$\underline{\text { Recipes }}$}

1. HEPES-NaOH buffer

$1 \mathrm{M}$ Hepes ( $\mathrm{pH} 7.8)$

Formaldehyde concentration (approx. 11\%)

Use one-tenth volume to crosslink

* Make up the HEPES-NaOH but add formaldehyde only before use. This is a 10x stock.

2. ChIP lysis buffer

$50 \mathrm{mM}$ Tris- $\mathrm{HCl}(\mathrm{pH} 8.0)$

10 mM EDTA

$1 \%$ SDS

+ Protease inhibitors

3. RIPA buffer (1x)

$10 \mathrm{mM}$ Tris- $\mathrm{HCl}(\mathrm{pH} 8.0)$

1 mM EDTA

$0.5 \mathrm{mM}$ EGTA

$140 \mathrm{mM} \mathrm{NaCl}$

$1 \%$ Triton $\mathrm{X}-100$

$0.1 \%$ Sodium deoxycholate

$0.1 \%$ SDS

+ Protease inhibitors

4. Digesting buffer

$50 \mathrm{mM}$ Tris- $\mathrm{HCl}$ (pH 8.0)

$1 \mathrm{mM}$ EDTA 
$100 \mathrm{mM} \mathrm{NaCl}$

$0.5 \%$ SDS

(Some people like to add $100 \mu \mathrm{g} / \mathrm{ml}$ proteinase $\mathrm{K}$, but since you are going to heat the sample at $65^{\circ} \mathrm{C}$, and then do a phenol chloroform extraction, it's not really necessary). 